\title{
ASSESSMENT OF UNDERGROUND WATER POTENTIAL ZONES USING MODERN GEOMATICS TECHNOLOGIES IN JHANSI DISTRICT, UTTAR PRADESH, INDIA
}

\author{
Niraj Kumar Pandey ${ }^{a}$ Anoop Kumar Shukla ${ }^{b}$ *, Satyavati Shukla ${ }^{c}$, Mamta Pandey ${ }^{d}$ \\ ${ }^{a}$ Department of Geology, University of Delhi, India - nirajgeomatics@ yahoo.com \\ ${ }^{\mathrm{b}}$ Department of Civil Engineering, IIT Roorkee, India - anoopgeomatics@ gmail \\ ${ }^{c}$ CSRE, Indian Institute of Technology Bombay, Mumbai, India - satyageomatics@ gmail.com \\ ${ }^{\mathrm{d}}$ GIS Cell, MNNIT Allahabad, Uttar Pradesh, India - mamta.mnnit@ gmail.com
}

Commission VI, WG VI/4

KEY WORDS: Geomatics, Ground water, Landsat TM, Rainfall, Satellite data

\begin{abstract}
:
Ground water is a distinguished component of the hydrologic cycle. Surface water storage and ground water withdrawal are traditional engineering approaches which will continue to be followed in the future. The uncertainty about the occurrence, distribution and quality aspect of the ground water and the energy requirement for its with drawal impose restriction on exploitation of ground water. The main objective of the study is assessment of underground water potential zones of Jhansi city and surrounding area, by preparing underground water potential zone map using Geographical Information System (GIS), remote sensing, and validation by underground water inventory mapping using GPS field survey done along the parts of National Highway 25 and 26 and some state highway passing through the study area. Study area covers an area of $1401 \mathrm{~km}^{2}$ and its perimeter is approximate $425 \mathrm{~km}$. For this study Landsat TM $(0.76-0.90 \mathrm{um})$ band data were acquired from GLCF website. Sensor spatial resolution is 30 $\mathrm{m}$. Satellite image has become a standard tool aiding in the study of underground water. Extraction of different thematic layers like Land Use Land Cover (LULC), settlement, etc. can be done through unsupervised classification. The modern geometics technologies viz. remote sensing and GIS are used to produce the map that classifies the groundwater potential zone to a number of qualitative zone such as very high, high, moderate, low or very low. Thematic maps are prepared by visual interpretation of Survey of India topo-sheets and linearly enhanced Landsat TM satellite image on 1:50,000 scale using AutoCAD, ArcGIS 10.1 and ERDAS 11 software packages.
\end{abstract}

\section{INTRODUCTION}

Ground water is a distinguished component of the hydrologic cycle. Surface water storage and ground water withdrawal are traditional engineering approaches which will continue to be followed in future. The uncertainty about the occurrence, distribution and quality aspect of the ground water and the energy requirement for its withdrawal impose restriction on exploitation of ground water. In spite of its uncertainty, ground water has some obvious advantages. These advantages of ground water is that it is much protected from pollution; it requires little treatment before it use; it is available almost everywhere; it can be developed with little gestation period and can be supplied at a fairly steady rate. It does not require any distribution system and its interference with land resources is minimum. In hilly region, the ground water emerging as springs can serve as a viable source for supply of drinking water. In a canal command area, use of ground water controls the water logging problems. The role of ground water is conspicuous during period of drought. According to Gazetteer of the Jhansi district (Prasad, 2008), Jhansi lies in the Southwestern part of the Uttar Pradesh between $25^{\circ} 07^{\prime}$ and $25^{\circ} 57^{\prime}$ North latitude and $78^{\circ} 10^{\prime}$ and $79^{\circ} 25^{\prime}$ East longitudes. It has an irregular boundary, the northern being contiguous with that of the district of Jalaun, the river Betwa flowing between the two districts for a considerable distance. Total Geographical areas of the district is 5024 sq. $\mathrm{km}$. District headquarter is at
Jhansi and there are eight numbers of blocks in the district. (Kharad et al., 1999). Water resources assessment of a region involves a detailed study of the surface and sub-surface water. Integration of the entire surface and sub-surface data manually, requires huge manpower and time. By adopting a GIS platform the result obtained will be faster and more accurate. (Kumar, 1992) carried out the review on status of developments in hydrological studies related to ground water hydrology including review of the basic concepts and associated methodologies. In Jhansi district, Main source of irrigation is through ground water and canal. The total length of canal is $1236 \mathrm{~km}$ by which 75235 hectare area is irrigated. There are 89 number of government tube wells through which 3806 hectare area is irrigated. Irrigation by private tube well is 8678 hectare. Hence $54 \%$ area is irrigated by ground water. Net sown area is 326767 hectare and net irrigated area is 196078 ha. The ratio of net irrigated area to net sown area is $60 \%$. For drinking water supply pipe line schemes and India Mark II hand pump exist in the district. There are 739 India Mark II hand pumps for providing water to 863342 persons. The area is chiefly drained by the river Betwa and minor rivers such as Dhasan and Pahuj. The Betwa and Pahuj rivers are tributaries of Yamuna and Dhasan is tributary of Betwa. The major tributaries of Dhasan are the Lakheri, Sukhnai, Kurera, etc. which are mainly ephemeral. All three main rivers are perennial.

\footnotetext{
* Corresponding author.
} 


\section{STUDY AREA}

Study area covers an area of 1401 sq. $\mathrm{km}$ and its perimeter is approx $425 \mathrm{~km}$. It covers the following Survey of India toposheet numbers: $54 \mathrm{~K} 6,7,10,11,14$, and 15 . The area extent is bounded between the longitude $78^{0} 15^{\prime} \mathrm{E}$ to $79^{\circ} \mathrm{E}$ and latitude $25^{0} 15^{\prime} \mathrm{N}$ to $25^{\circ} 45^{\prime} \mathrm{N}$. The average annual rainfall is $850.1 \mathrm{~mm}$. The climate is sub-humid and it is characterized by a hot dry summer and cold winter. About $91 \%$ of rainfall takes place from June to September. During monsoon surplus water is available for charging to ground water. January is the coldest month of the year when the mean daily maximum temperature is $24.1^{\circ} \mathrm{C}$ and the mean daily minimum temperature is $9.2^{\circ} \mathrm{C}$, May is the hottest month with mean daily maximum temperature $46^{\circ} \mathrm{C}$ and mean daily minimum temperature is $28.8^{0} \mathrm{C}$. The mean monthly maximum temperature $32.6^{\circ} \mathrm{C}$ and mean minimum temperature is $19.2^{\circ} \mathrm{C}$. In the summer season air is very dry and during the monsoon season the moisture content of air is high. The mean monthly relative humidity is $37 \%$. During the post monsoon and winter season winds are light and in the summer and monsoon season the winds strengthen slightly. The mean wind velocity is $4.8 \mathrm{Kmph}$. The potential evapotranspiration is $1603.3 \mathrm{~mm}$. The Geographical location and other details of study area are given in Figure 1.

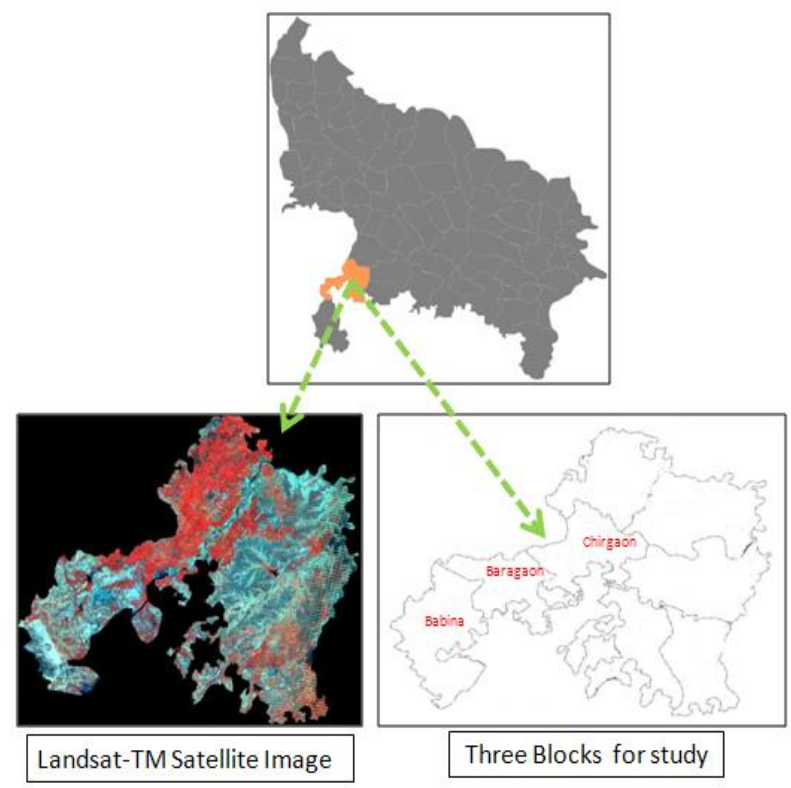

Figure 1: Location map of Study Area

\section{METHODOLGY}

In the first step all the datasets have been converted to the digital format by scanning of existing maps. All datasets were geo-referenced and resampled using the nearest neighborhood method. Second step involves generation of thematic layers such as LULC, water (Figure 5), settlement layer, road network, drainage network (Figure 7), geology (Figure 4), slope, aspect and lineament (Figure 9). Third step involves conversion of the dug well / bore well location and depth of water level information to digital format. Various standard digital image processing techniques were applied to Landsat TM data to enhance and extract information from visual interpretation. Contrast stretching of individual bands is effective in improving interpretability of different features and unsupervised classification was used for generation of different thematic layers. An elevation contour map was digitized from SOI toposheet at 10 meter contour interval and linear interpolation of these data led to the generation of a digital elevation model (DEM) (Figure 2). The point locations of 30 wells were digitized and water table data was interpolated (Figure 3). Linear interpolation of water table contour map led to the generation of the ground water surface. The fourth step involves the generation of the GIS database. A base map was generated from SOI toposheet at 1:50,000 scale comprising of surface drainage features and location of settlement areas. All data was geo-referenced to the base map. The fifth step consists of integration of multidisciplinary datasets into a composite information set. There are two major aspects of integration (a) The criterion defining the logic of the analysis (b) The relative weightage of the parameter. The criterion for any analysis is dependent on the objective and also the data sets. On the basis of relative importance, a set of weights were decided for different information layers and the best suitable condition was derived.

\section{RESULTS AND DISCUSSION}

The most common remote sensing tools used for the detection of underground water are various satellite images. Satellite image has become a standard tool aiding in the study of underground water. Extraction of different thematic layers like land use land cover, settlement, etc. can be done through unsupervised classification. Land use data are required for estimating the evapotranspiration losses from the water table through forested area. Cropping pattern data are necessary for estimating the spatial and temporal distributions of groundwater withdrawals, if required. Monthly pan evaporation rates have been used at few locations for estimation of consumptive use requirements of different crops. After generation of this thematic layer from the satellite image (Figure 8), the area was calculated for different types of land use /land cover (Figure: 6). The modern geometics technologies viz. remote sensing and geographical information system were used to produce map that classifies the groundwater potential zone to a number of qualitative zones such as very high, high, moderate, low or very low. Thematic maps were prepared by visual interpretation of Survey of India toposheets and linearly enhanced Landsat TM and on 1:50,000 scale using AutoCAD, ArcGIS 10.1 and ERDAS 11 software. The multivariate's statistical techniques were used to find out the relationship between rainfall and ground water resources. It has been observed that underground water not only depends upon the rainfall, but on various other factors which affect its occurrence. In this research paper, some important parameters were considered and multicreation analysis has been carried out in order to find out the underground water potential zones. The relation between the rainfall and groundwater characteristics has been studied by using multivariate intercorrelation techniques. The results of ground water not only depend upon the rainfall but also on other factors like drainage, lineament, slope and land use. By incorporating all these factors, a weighted index model could be created for identifying the groundwater potential zones. The surface investigation of ground water potential using remote sensing and GIS is proved to be an easier as well as a challenging method in identifying the groundwater resources. Multicriterion evaluation is performed by assigning weights to all the parameters and the result were derived out of multicriterion evaluation. The spatial database developed during this 
study can be improved by adding further information layers and a modeling approach may be adopted in future using integrated GIS.

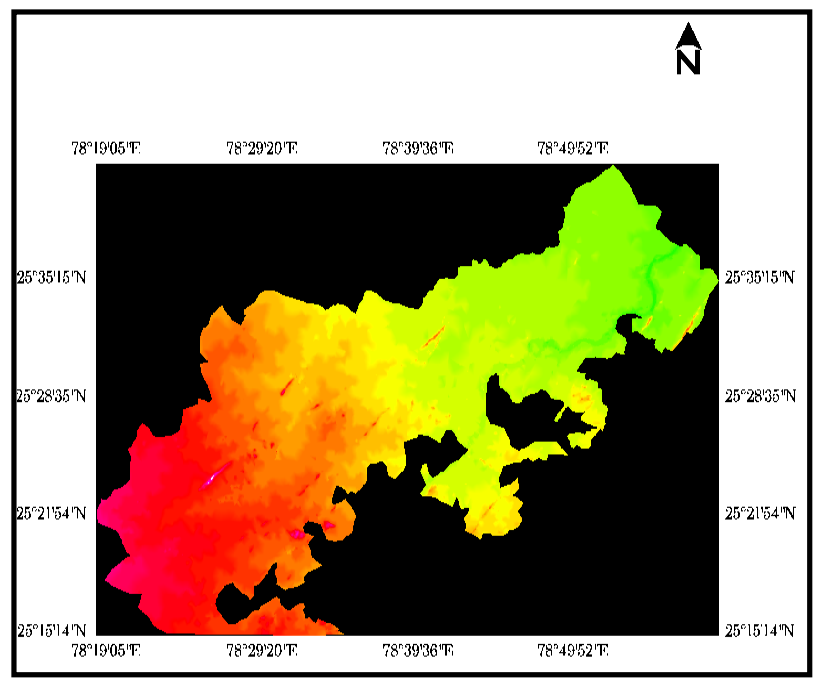

Figure 2: Digital elevation model of the study area

The final map clearly shows Babina block and some part of Baragaon block with good and moderate ground water potential zones as compared to Chirgaon block (Figure 10). In the Jhansi district, most of the area comes under drought with variation of water level depth in present dug well / bore well (Figure: 3). Hence, it is important to study the prognostic vulnerable locations where major variation in water level may take place. For that purpose, assessment of underground water potential zone involve topographical and geological mapping in order to carry out spatial analysis (Figure: 4 ).

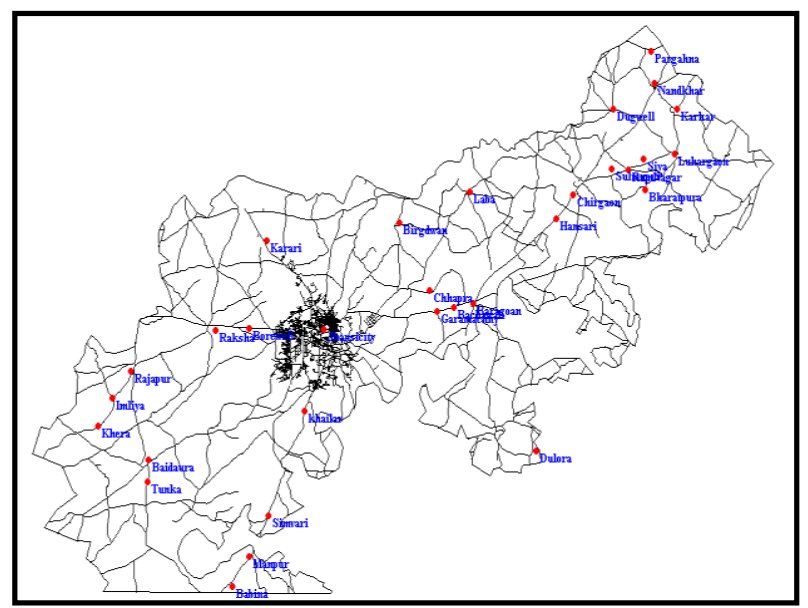

Figure 3: Location of dug well/bore well map of study area

Mapping techniques were based on themes and scales. They were carried out depending upon distance between available dug wells / bore wells and other factors. The water table marks the level to which the ground is fully saturated (saturated zone) and reaches the surface at most rivers and all groundwater-fed lakes. Above the water table the ground is known as the unsaturated zone. The productivity of an aquifer depends on its ability to store and transmit water, and these qualities may vary. Unconsolidated granular sediments, such as sand or gravel contain pore space between the grains and thus the water content can exceed $30 \%$ of the volume. This is reduced progressively as the proportion of finer materials such as silt or clay increases and as consolidation occurs, typically accompanied by cementation of the grains. In highly consolidated rocks groundwater is found only in fractures and rarely exceeds $1 \%$ of the volume of the rock mass. However, in the case of limestone, these fractures may become enlarged, by solution and preferential flow to form fissures and caverns. Even then, the total storage is relatively small compared with unconsolidated aquifers. One result is that there is less water available to dilute contaminated water that finds its way into the system. Groundwater systems are dynamic and water is continuously in slow motion down gradient from areas of recharge to areas of discharge.

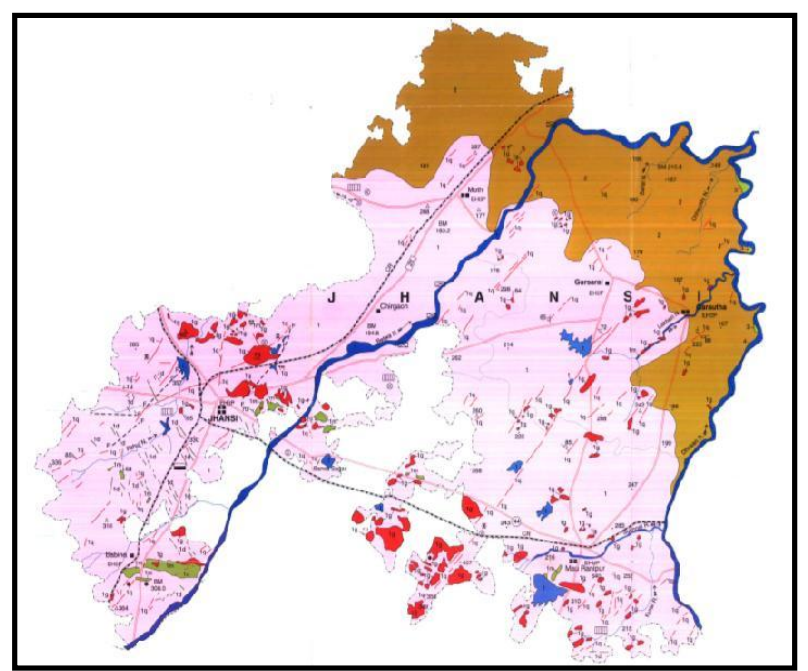

Figure 4: Geological map of the study area

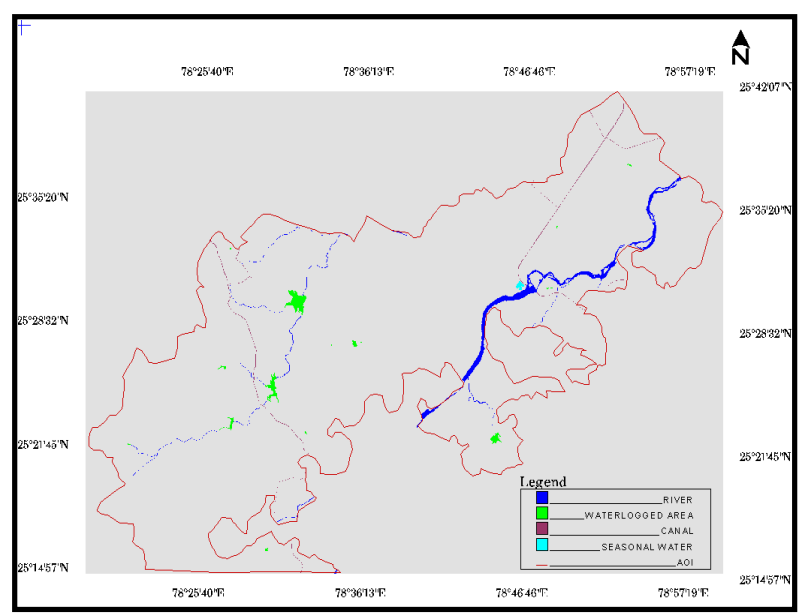

Figure 5: Water map of the study area

\section{CONCLUSIONS}

The relation between the rainfall the groundwater characteristics were studied by using Multivariate intercorrelation techniques. The relation between the rainfall and groundwater characteristics has been studied by using Multivariate inter-correlation techniques. 


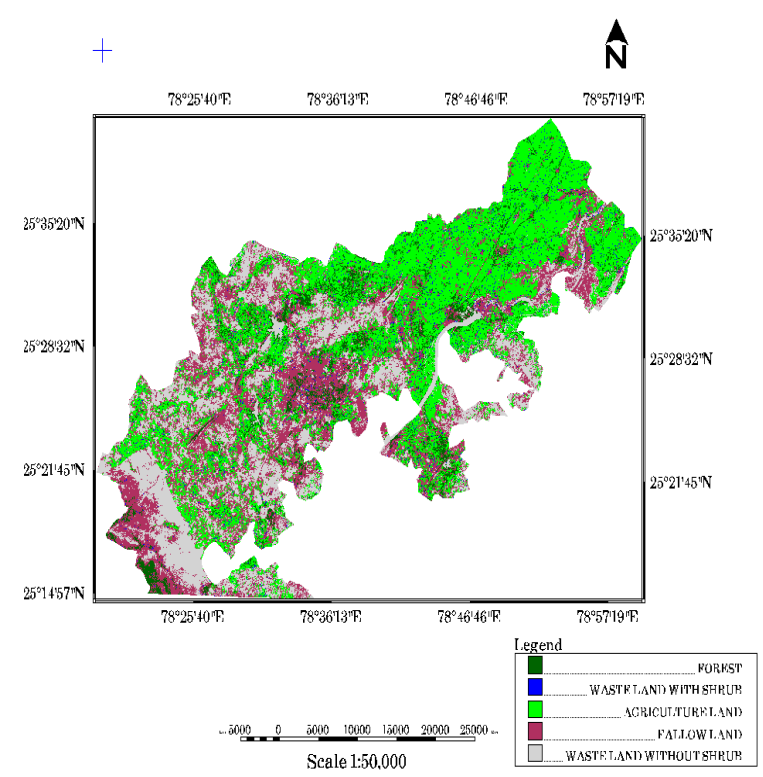

Figure 6: LULC map of the study area

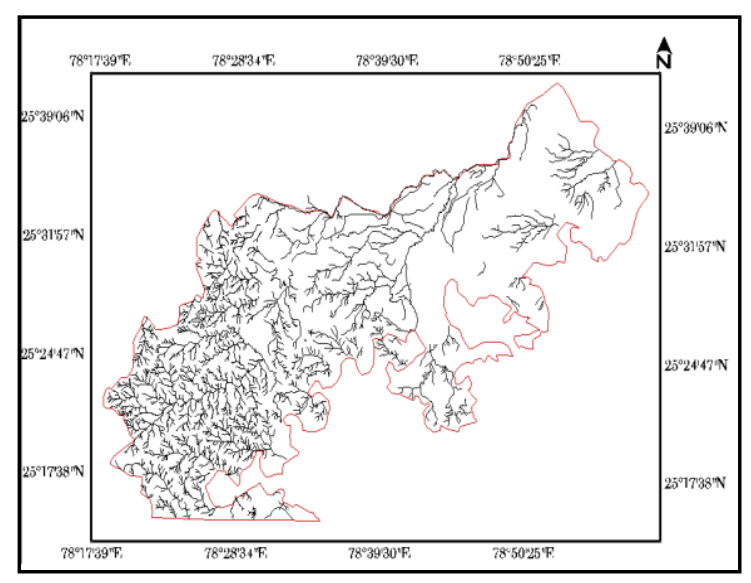

Figure 7: Drainage network map of the study area

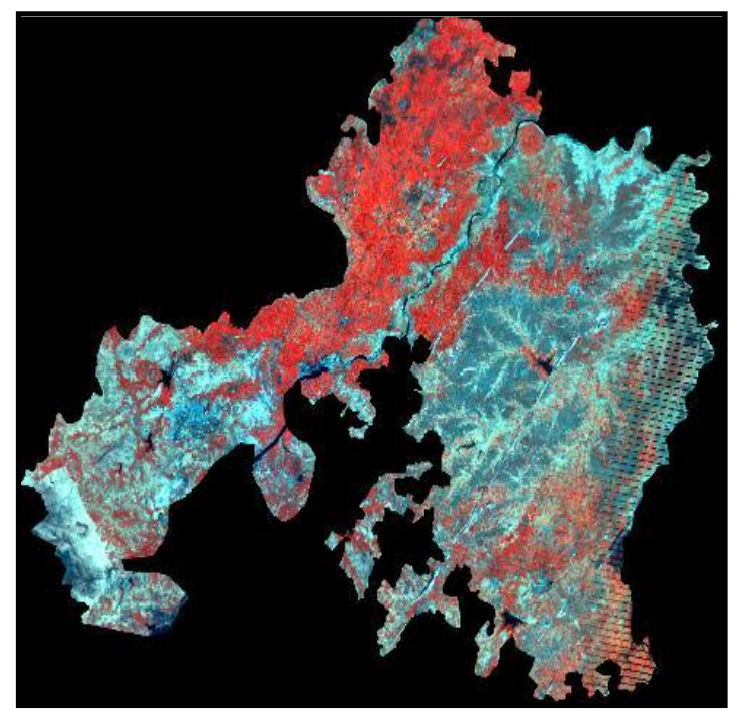

Figure 8: Satellite image (map) of the Jhansi district

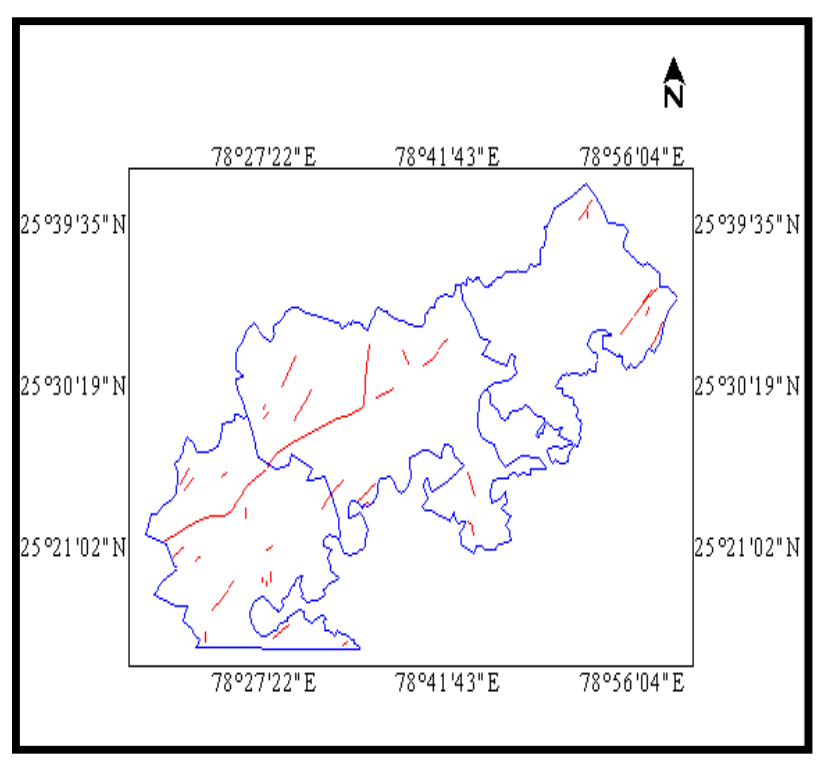

Figure 9: Lineament map of the study area

The results of ground water not only depend upon the rainfall but also on other factors like drainage, lineament, slope and land use. By incorporating all these factors, a weighted index model could be created for identifying the groundwater potential zones. The surface investigation of ground water potential using remote sensing and GIS platform has proved to be an easier as well as a challenging method in identifying groundwater resources. Multi-criterion evaluation has been performed by assigning weights to all the parameters and the result derived out of multi-criterion evaluation. The spatial database developed during this study is being improved by adding further information layer and a modelling approach may be adopted in future using integrated GIS. The final map clearly shows Babina block and some part of Baragaon block has good and moderate ground water potential zones as compared to Chirgaon block (Figure 10).

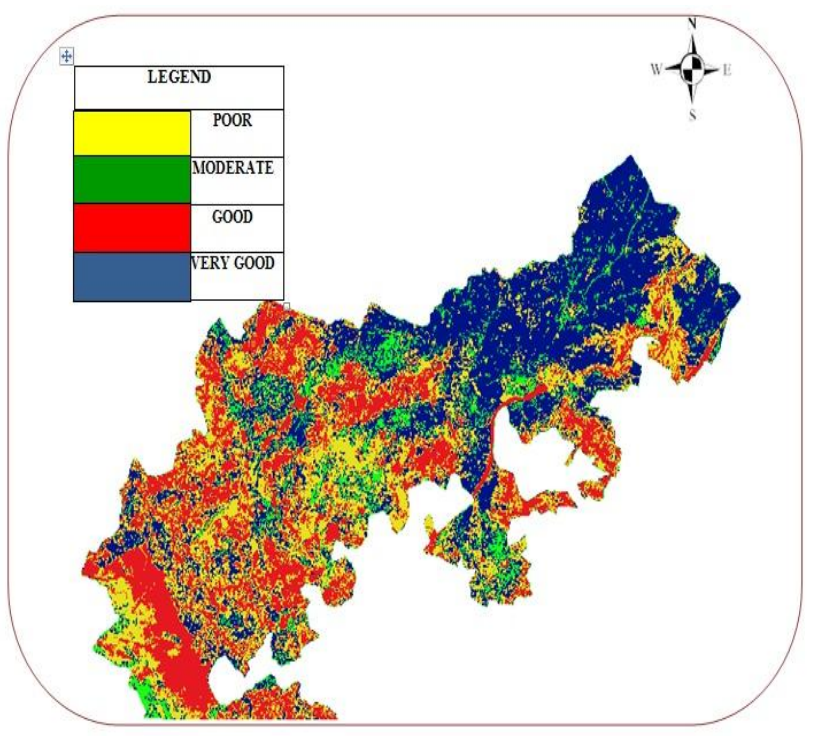

Figure 10: Final map of underground water potential zone 


\section{REFERENCES}

Prasad, J., 2008. A ground water brochure of Jhansi district, Uttar Pradesh, India (A.A.P. 2007-2008). Hydrogeology of the Bundelkhand region, Central Ground Water Board, Government of India.

Kharad, S.M., Rao, K.S. and Rao, G.S., 1999. GIS based groundwater assessment model, GIS Development, Nov-Dec 1999. Available online at: http://www.gisdevelopment. Accessed on: August 05, 2014.

Kumar, C. P., 1992. Report on the Ground Water Modelling. Hydrological Developments in India since Independence, A Contribution to Hydrological Sciences, National Institute of Hydrology, Roorkee, pp. 235-261. 